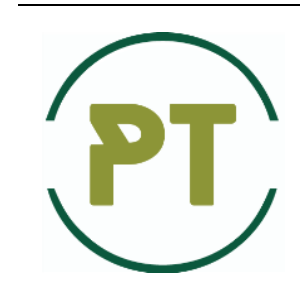

Problems of Tribology

Website: http://tribology.khnu.km.ua/index.php/ProbTrib

E-mail: tribosenator@gmail.com

DOI: https://doi.org/10.31891/2079-1372-2020-95-1-16-25

\title{
Ways of reducing of friction surfaces wearing by using of triboelectric phenomena
}

\author{
S. Kryshtopa ${ }^{*}$, L. Kryshtopa, F. Kozak, V. Melnyk, T. Dykun, M. Tseber \\ Ivano-Frankivsk National Technical University of Oil and Gas \\ *E-mail: auto.ifntung@ukr.net
}

\begin{abstract}
The purpose of the work is to establish the patterns of variation in the wear-friction properties of surface layers of metal-polymer friction pairs that are in the process of mechanical, thermal and electrical interaction in the friction units of brake devices, taking into account triboelectric phenomena.

Experimental studies of triboelectric processes were carried out on a specially created laboratory stand that modelled band-block brake of technological transport and on the serial universal brake stand of the KI-8964 model which makes it possible to investigate metal-polymer pairs of friction of drum-block and disc brakes. Measurement of tribological current was carried out with the help of the n-ampere meter, and the potential difference - with the help of the analog-to-digital converter USB Oscilloscope II.

As a result of the carried out investigations of the friction properties of metal-polymer friction pairs of brake devices under laboratory and operating conditions the laws of change are established for triboelectric interaction: the values of the contact difference of the potentials of friction pairs "grey cast iron-polymers" of drum-block and band-block brakes from surface temperature of linings and specific loads; the dynamic coefficient of friction from the values of circulating thermal and tribological currents; the values of the braking moments produced by individual friction units and the total brake moments from the change in the generated tribological currents in the contact of the two-layer "metal-polymer" structures.

The conducted studies of triboelectric phenomena in metal-polymer friction pairs allow expanding the database on triboelectric processes in brake devices. As a result of the studies of the wear and tear properties of metal-polymer friction pairs of brake devices in laboratory and operating conditions on the nano-, micro- and milli-levels during the triboelectric interaction regularities have been established for the variation of the thermally-stimulated discharge currents and electric potentials in the frictional contact pairs from the time of friction interaction, the surface temperature of the linings and the specific loads, the dynamic coefficients of friction and the braking moments from the values of generated tribological currents.

The obtained results allow optimize management of wear and tear friction properties and heat state of braking units.
\end{abstract}

Key words: drum brake, band brake, metal-polymer friction pairs, tribosystem triboelectric processes.

\section{Formulation of the problem}

Problem of figuring out mechanisms of friction is still far from being solved at present. One of reasons is due to the fact that in the process of friction interaction due to the effect of electrical effects that occur in contacts of metal-polymer tribulations during friction processes there are significant changes in properties of friction surfaces of metal-polymer materials which significantly affect their tribo characteristics. Work of a considerable number of scientists is devoted to study of triboelectric phenomena in surface layers of metal-polymer friction pairs, however, many studies provide rather contradictory information, and these or other issues of triboelectric friction interaction have been left unaddressed by scientists. In particular, mechanisms of influence of triboelectric phenomena on wear properties of friction surfaces of metal-polymer pairs of braking mechanisms have not yet been established. Establishing regularities of triboelectric interaction of friction pairs of brakes is relevant in terms of implementation of new methods of reducing wear of metal-polymer friction pairs of various friction units. 


\section{Analysis of recent research}

Studies of contact processes between two metals, metals and semiconductors have been extensively conducted at present. Thus, in [1] triboprocesses were investigated in layers of lubricating oil in sliding bearings, in [2] influence of dynamic loads on resistance of tribocontacts was investigated, in [3] issues of triboprocessing optimization were studied, and in [4] triboelectric effects during drilling processes were investigated.

Considerable attention is given to study of triboelectric phenomena in friction pairs with layers of lubricants, given in $[5,6]$ and study of double electrofields occurring in contacts in presence of lubricants. Triboelectric effects during friction of samples from metals and composites have been studied in [7]. Values of circulating tribocurrents during and without friction for various composites were determined. It has been found that wear resistance of composite materials has on average doubled when using tribocurrents.

In [8], triboelectric phenomena in conditions of dry friction in friction pairs of homogeneous steel were considered. Main causes of triboelectric currents during friction and metal cutting, influence of geometrical parameters, electrical properties and cutting modes on value of electric currents were analysed. Ways of wear compensation for metal friction pairs by using of electrical phenomena to move dispersed metal particles on the friction contact surface are considered in [9]. Mandatory presence of friction contact in metal-to-metal pairs is established.

In [10], problem of electrical conductivity calculating of a rough contact was set. Formulae of determination of electric resistance for area of actual contact are offered. Due to complexity of determining the resistance of surface pellicles, established laws are true, mainly for precious metals.

Considerable attention is paid to electrochemical phenomena during friction processes. Thus, in [11], relationships between value of galvanic EMF and wear resistance of metals are established. The study performed electro-thermo-mechanical wear, which was explained from electrochemical positions, considered electrochemical processes that occurred in contact of metals with liquids, and established regularities of separation and movement of ions, and considered the wear of metal surfaces with regard to their isolated and grounded states.

The studies of triboelectric effects in metal-polymer and polymer-polymer pairs were performed less thoroughly. Thus, [12] investigated electrical conductivity of metal-polymer friction pairs and found that the conductivity of pure polymers is relatively low. But in presence of degradation, contamination and dissociation products, the conductivity of polymers begins to increase sharply. Mechanism of circulation of electric currents through the contact of the above friction pairs is explained by the passage of electrons from materials with less work of electron output to materials with more work and characteristics of friction contact, which is also devoted to a number of works. Thus, in [13] electron emission from solids surfaces during friction was studied. It has been found that electrons exit from the surfaces can estimate the state and defects of the friction surfaces and determine the level of surface energy. Influence of triboelectric phenomena during frictional interaction on the destruction of polymers was investigated. It has been found that during the friction processes, polymer molecules are destroyed and electrons are emitted from the surfaces.

Electrical properties of polymeric materials were studied in [14] very thoroughly. It has been found that the conductivity of polymers in the presence of copper compounds increases to two orders of value, and the sorption by polymer of water leads to an increase in the conductivity of polymers by several orders of value. It is established that the electrical conductivity of polymers increases by an order of value when the melting point is exceeded. The paper analyses circulating currents and studies conductivity of polymers as a function of their temperature and pressure.

Triboelectric phenomena in metal-polymer friction pairs significantly influence the mass transfer processes and the composition of the boundary layer, which determine the directions and magnitudes of triboelectric currents. Thus, in [15] effect of electrification phenomena in metal-polymer friction pairs on mass transfer processes was investigated. Both the transfer of metals to the polymer surface and the formation of polymer pellicles on the metal surface were investigated. But there is no explanation for mechanism of change tribo EMF, the only assumptions are made. In [16], processes of flooding in the metal-polymer pairs of the friction of tape and brake blocks, the directions of circulation of tribocurrents during friction were studied, and the increased wear of the friction surfaces of the metal-polymer pairs and the decrease of the braking efficiency were found. However, experimental data in $[14,15,16]$ did not always coincide with theoretical calculations.

\section{Isolation of unsolved part of common problem}

It should be noted that analysis of relevant literature sources indicates the uncertainty of the mechanisms of triboelectricity with respect to metal-polymer friction pairs and inconsistency of a large number of known studies. It should be noted that the state of surfaces for polymer facings and metallic friction elements is characterized by different physical nature, and between the wear-friction characteristics and triboelectric processes, the state of surfaces of metal-polymer friction pairs are quite ambiguous and contradictory. ulcers that significantly affect the wear of the friction surfaces. 


\section{The purpose of the study}

The purpose of the study is to investigate mechanisms of triboelectricity and to improve the wear properties of surface layers of metal-polymer friction pairs, which are in process of mechanical, thermal and electrical interaction, in metal-polymeric brake nodes taking into account triboelectric phenomena.

For solving of the problem the following tasks are outlined:

- to investigate mechanisms of metal-polymer friction pairs triboelectricization based on analysis of potential barriers and the work of electrons exit from the surface layers of friction elements;

- to find out connections of impulse currents in surface layers of friction mechanisms and temperature gradients in metal-polymer structures;

- to establish the influence on dynamic coefficients and wear of friction surfaces of values and directions of circulating electric currents in the brake pairs of the friction mechanisms.

\section{Methods of investigation of triboelectric processes in metal-polymer friction pairs}

Taking into account the research purposes, a brake stand with a model of band-block brake was designed and manufactured (Fig. 1).

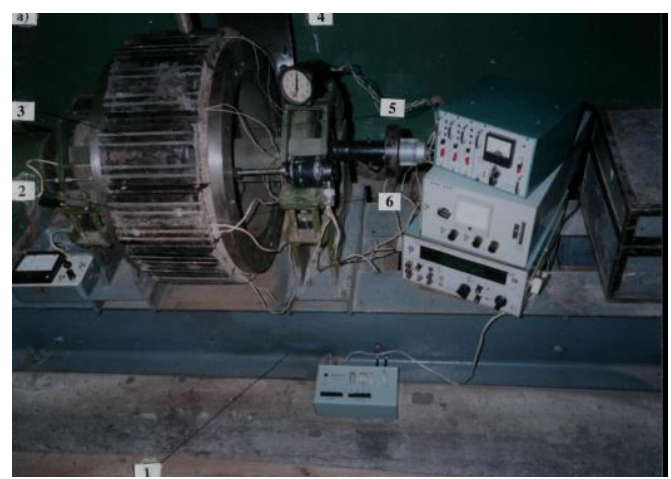

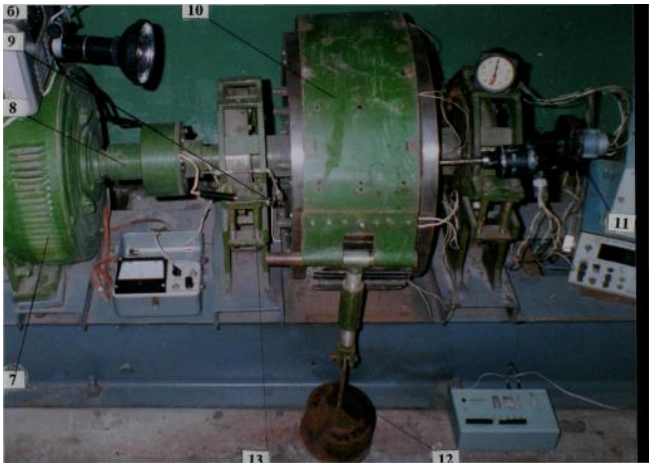

Fig. 1. General view of a stand of a band-block brake with open (a) and closed (b) brake bahd: 1 - frame beams;

2, 3, 4 - friction facings with external and internal working surfaces;

5 - brake pulley; 6 - thermocouple outputs;

7 - drive motor;

8 - a shaft of a brake pulley;

9 - nanoammeter outputs;

10 - brake band;

11 - tachometer;

12 - loading device;

13 - shaft supports

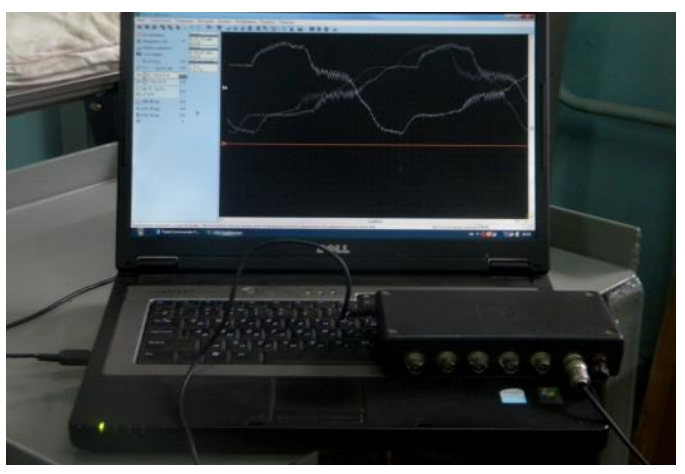

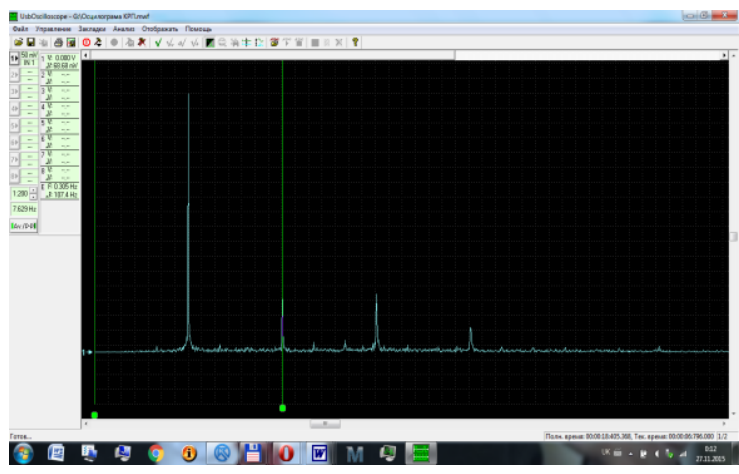

Fig. 2. Computer Oscilloscope USB oscilloscope (a) and contact differences of friction potentials of friction pairs "steel 34 L - retinax FC-24A" model tape brake (b)

The stand is intended to establish regularities of characteristics of triboelectric currents during electromechanical friction. Performing a sufficient number of tests of metal-polymer friction pairs in stand conditions allowed us to objectively judge the wear-friction process depending on generated electric currents. The brake 
stand fulfilled the following requirements:

- performance of long brakes for estimation of currents and temperatures on the surfaces of metalpolymer friction pairs;

- model of real working conditions of friction pairs of brakes with possibility of changing tribological parameters of their surface layers.

The following parameters were recorded: braking time and number of brakes; temperature and angular velocity of friction elements; tension of the filling and unfilling branches of band-block brake; values of wear and tear of friction surfaces; the directions and values of tribocurrents circulating between friction pairs; potential difference between friction pairs.

In order to capture the data of the change of the contact difference of the potentials of the frictional pairs on a personal computer, the contact surfaces of the friction were connected to the laptop via an analog-to-digital converter of the computer oscilloscope USB Oscilloscope II (Fig. 2, a). Obtained values of the contact difference between the potentials of friction pairs were recorded in real time, recorded on a computer hard disk and processed using the software of a computer oscilloscope USB Oscilloscope II.

Presentation of main material of studies of the wear-friction properties of friction pairs of brake devices

It is established that the contact potential difference consists of constant and variable components. The constant component depends mainly on materials of the contacting surfaces and surface temperatures, and impulse mainly depends on fluctuations of electrothermal resistance in contact and fluctuations in energy of the friction surfaces. It is found that impulse component significantly affects the wear-friction properties of friction pairs of friction units than value of constant component of contact potential difference. Fig. 2, b illustrates dependence of the alternating contact potential difference of the friction pairs "gray cast iron NF 20 - cipher 1$43-60 \mathrm{~A} "$ of the band-block brake at $350^{\circ} \mathrm{C}$ recorded using a digital oscilloscope USB computer oscilloscope.

Ability of any tribological material to conduct electric current is determined by the presence of charges in them (electrons, ions) and possibility of their movement through the volume of material. Write the total dependence for the current density $j$, which is true for any medium except vacuum:

$$
j=\sum n_{i} q_{i} b_{i}
$$

where $i$ - type of charge (e.g. electrons, ions of different molecules, charged particles, etc.);

$n_{i}$ - concentration of charges of $i$ type;

$q_{i}$ - magnitude of the charge;

$b_{i}$ - velocity of charge carriers.

Dependence of the current density $j$ on the metal friction element is described by the RichardsonDashman formula:

$$
j=C T^{2} e^{-\frac{W}{k T}}
$$

where $T$ - surface temperature of metal friction element;

$C$ - constant which depends on the properties of material and surface;

$k$ - Boltzmann constant;

$W$ - the output work of electrons from the metal element surface at given temperature.

If the Richardson-Dashman formula will be recorded as $\frac{j}{T^{2}}=C e^{-\frac{W}{k T}}$, so after its logarithm we get:

$$
\ln \frac{j}{T^{2}}=\ln C-\frac{W}{k T} \ln e .
$$

Let us represent obtained expression for two values of temperatures $T_{1}$ and $T_{2}$ of metal friction element that corresponds to the temperature value before and after braking process. We will take into account that $j=\frac{I}{A}$ (where $I-$ alternating current circulating in the friction pair in the area with the area $A$ ). Then we get the following dependencies: 


$$
\begin{gathered}
\ln \frac{I_{1}}{A T_{1}^{2}}=\ln C-\frac{W_{1}}{k T_{1}} \\
\ln \frac{I_{2}}{A T_{2}^{2}}=\ln C-\frac{W_{2}}{k T_{2}} .
\end{gathered}
$$

If we subtract (4) from equation (5), then we obtain:

$$
\ln \frac{I_{2} T_{1}^{2}}{I_{1} T_{2}^{2}}=\frac{W_{1}-W_{2}}{k}\left(\frac{1}{T_{1}}-\frac{1}{T_{2}}\right),
$$

which will turn into a calculated dependence of determining the electron output from a metal friction element:

$$
W_{2}=W_{1}-k\left(\ln \frac{I_{2} T_{1}^{2}}{I_{1} T_{2}^{2}} / \frac{1}{T_{1}}-\frac{1}{T_{2}}\right) .
$$

Wear of friction surfaces is significantly influenced by the contact potential difference and surface temperature of contacting bodies. If one of the bodies is heated more then electron or ionic thermal currents are sent from it to the second body. The potential difference also increases as the area of the contacting bodies increases. Charges of contacting bodies have different signs but the same size. Interaction of metal-polymer friction pairs determines the type of contact and its energy level (Fig. 3). The main characteristic of the energy level of this or that contact is the work of the electron exit from the surface layer of the metal friction element $\left(W_{M}\right)$ and ions from the surface layer of the polymer facing $\left(W_{n}\right)$.

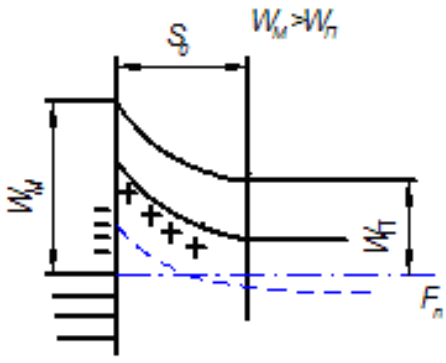

a

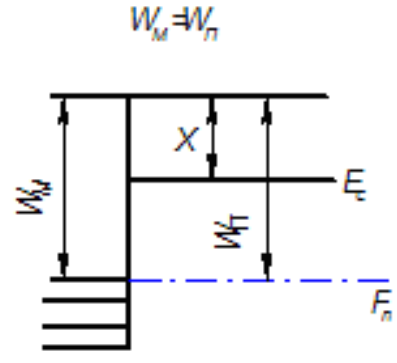

b

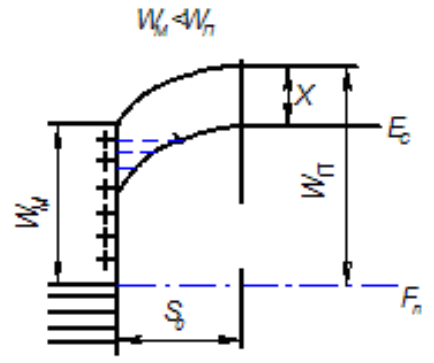

c

Fig. 3. Energy levels of brake metal-polymer pairs with injected (a), neutral (b), and injecting (c) types of contacts:

$S_{0}$ is the thickness of a layer enriched (b) and depleted (c) by electrons

Friction brake facings are made of non-uniform materials in the volume of which crystalline and amorphous phases coexist, therefore, different charges are captured at the interfacial boundaries. Due to difference in phase conductivity charges accumulate at the boundaries. When material is electrified, the overlays of the charge carriers will move away from the interfacial boundary or vice versa depending on which of the conductivity currents will be greater: the one moving from the charge boundary or the one moving towards it. For charge circulation processes, the properties of the interaction contacts, which are divided into neutral, injectable and injected, play a significant role. In Fig. 3, a, b, c difference in energy levels between neutral, injectable and injected contacts is shown. Neutral contacts of brake pairs do not support the circulation of electric charges between metal and polymer friction elements. For injection contacts charge carrier (injection) is moved to the charged surface of the polymer facing. Injected contacts are reversed: they help move charge carriers from the charged surface of the polymer pad to the metal friction element.

The type of contact depends on which of the electron or ion output work is larger: of metal or polymer friction element. If polymer element output work is less than metal one an injected contact is formed (Fig. 3, a) and the metal surface is charged negatively. If the output works are the same, then there will be a neutral type of contact (Fig. 5, b), if the polymer friction element output work is greater than the metal friction element output work, then the metal surface is charged positively and we have an injecting type of contact (Fig. 3, c).

Let's note, furthermore, that the spots of the contacts of the micro protrusions, which are covered by the pellicle, are blocking contacts at low field strength. That is, such a contact prevents the transfer of charge carriers from the micro-projections of the metal friction element to the surface layer of the polymer friction facing, at the 
same time, it cannot accept the carriers from the above layers. Stationary current is not possible in dielectrics with blocking contacts that do not contain charge carriers at all. If the metal element output work is greater than the polymer element output work $\left(W_{M}<W_{n}\right)$ then upon contact of the metal with the polymer, the electrons from the polymer will pass to the metal, since the Fermi level in the polymer before frictional interaction with the metal was higher than in the metal $\left(F_{M}<F_{n}\right)$. The metal is charged with a negative charge and the polymer is positive. A directional electron flux will take place before the Fermi levels are equalized.

Circulating tribostrums have been found to cause surface temperatures to rise and wear in friction pairs, and usage of tribocurrents suppressants can reduce temperatures and wear of friction surfaces. In order to improve the performance of the braking mechanisms, in particular the reduction of wear and surface temperatures, the comparison of series band-block, drum-block and disc-block brakes and advanced brake designs with depolarization devices reducing triboelectric phenomena in friction pairs.

For this purpose an additional power supply unit was connected to the friction units made of metalpolymer pairs and to Fig. 4a shows the value of the potential barrier to power on. However, if an external voltage was applied to the metal-polymer pair in the opposite direction to the potential contact difference (the "plus" is applied to the metal friction element, Fig. 4, b), then the potential barrier from the polymer facing is reduced (Fig. 5, c) and value of triboelectric current increased. We will call this connection generating.

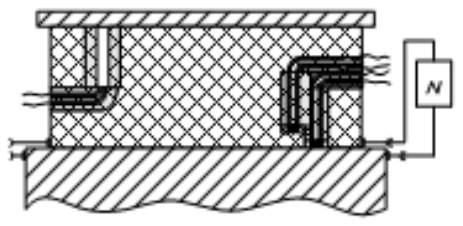

a

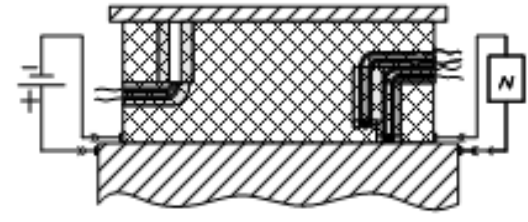

b

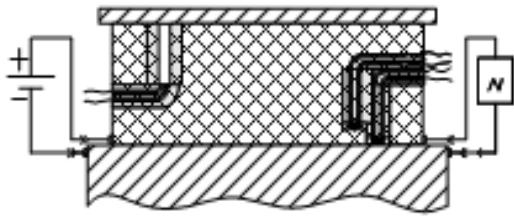

Fig. 4. Scheme of serial (a), generating (b) and blocking (c) connection of an external electrical source to band-block brake: 1 - a brake pulley; 2 - a friction facing; 3 - a brake band

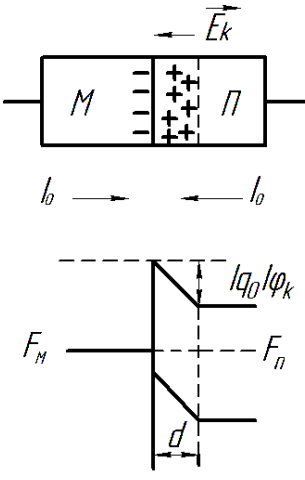

a
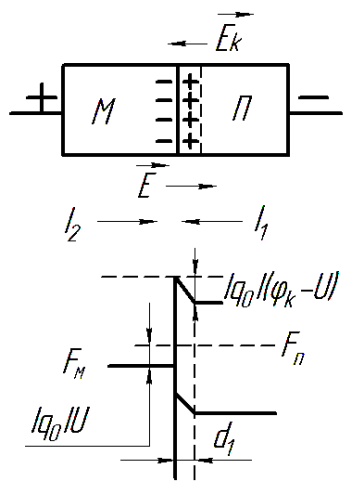

b

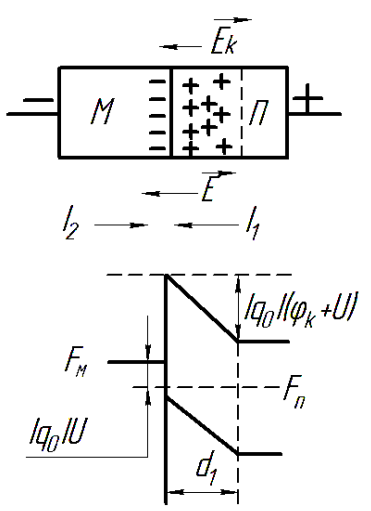

c

Fig. 5. Energy levels of metal-polymer brake pairs influencing by additional electric field: $\mathrm{a}$ - in the absence of a field;

$b, c-$ at the action of the field: accelerating, decelerating

If an external voltage is applied to a metal-polymer pair in a direction coinciding with the contact potential difference (a minus is shown on the metal friction element, Fig. 4, c), then the potential barrier on the side of the facing increases (Fig. 5, b) and the value of triboelectric current will decrease. This connection is called blocking one. As shown by the conducted experimental researches at generating temperature connection and wear of surfaces of friction pairs increase and at blocking connection they will decrease.

The regularities of changes in the surface temperatures of friction pairs "steel $35 \mathrm{CML}$ - retinax FC-24A" for serial band-block brake and band-block brake with a system of tribocurrents reduction by the number of cycles of braking $m$. Values of the generated currents: for serial band-block brake - $60 \mathrm{nA}$, for bandblock brake with system of reduction tribocurrents - $10 \mathrm{nA}$. The maximum surface temperatures on the working surface of rim of the pulley of the improved band-block brake of agregate AORS- 80 with system of tribocurrents reduction by $14.5 \%$ and the friction facings are $14.3 \%$ lower than that of the serial band-block brake. 
One of the main operational parameters of the band-block brake are tension of filling $\mathrm{S}_{3}$ and unfilling $S_{\mathrm{H}}$ branches of the band, the difference of which determines the friction force $\left(F_{T}=S_{H}-S_{Z}\right)$. In this case, one of the tension of the brake tape is determined by a given value and the second parameter is calculated. Preferably determine the tension of the unfilling band branch according to Euler:

$$
S_{H}=S_{Z} e^{f \alpha}
$$

Dynamic friction coefficient is determined by formula:

$$
f=\frac{S_{H}-S_{Z}}{N}=\frac{F_{T}}{N} .
$$

In Fig. 6 results of industrial studies of the friction coefficient change laws of friction pairs "steel $34 \mathrm{~L}$ - retinax FC-24A" and "steel 60G - code 6KF-59" of the brake devices of the units UPA-60 and A2-32 are shown with respect to values of sliding velocitys and generated currents.

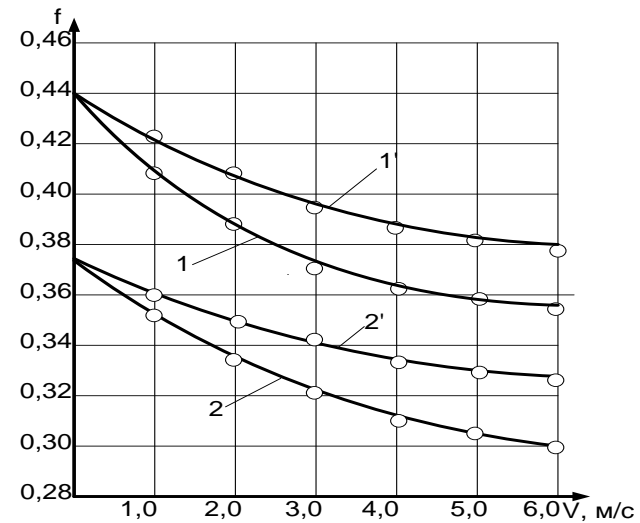

Fig. 6. Patterns of change of dynamic friction coefficient of friction pairs "steel 60G - code 6KF-59" (1) and "steel 34 L - retinax FC-24A" (2) of the brake devices from values of the sliding velocitys and generated currents with depolarizing device: $1-I=70 n A ; 1^{\prime}-I=15 n A$ $2-I=60 n A ; 2^{\prime}-I=10 n A$

One of the main operational parameters of friction pairs is intensity of wear on their surfaces. Regularities of changes of linear wear of working surfaces of friction facings of band-block brake with metal polymers friction pairs steel $34 \mathrm{~L}$ - retinax FC-24A APRS-50KAM for serial brake and using the device suppression tribocurrents are llustrated in Fig. 7. Investigations of the wear rate of the working surfaces of friction facing were performed for the serial brake without usage of tribocurrent reduction means and with the use of the tribocurrent suppression device at different electrification currents. It was found that linear wear of the friction facing surfaces for an improved band-block brake design is on average 20 - $30 \%$ less than facing surface wear for serial brake construction.

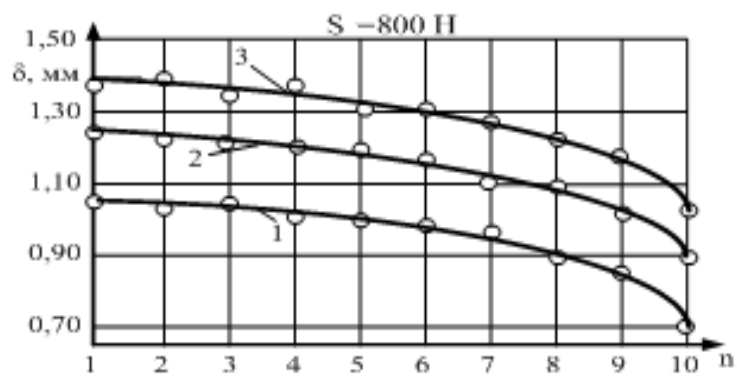

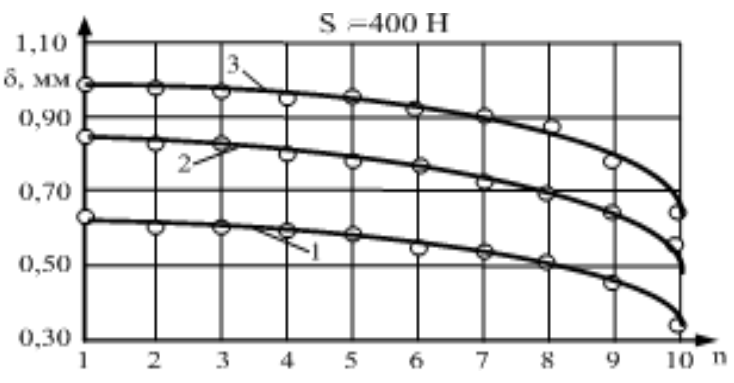

b

Fig. 7. Patterns of change of values of linear wear of surfaces of the model band-block brake facings at the tension of the filling branch of the brake band $S_{z}=800 \mathrm{~N}$ (a) and $S_{\mathrm{Z}}=400 \mathrm{~N}(\mathrm{~b})$ :

$1-I=70 n A$ (serial friction unit);

$2-I=50 n A$;

$3-I=25 n A$ 
As it was noted, during experimental studies, dependence of electrical potential formed on the contacting surfaces was determined from capacity of the metal friction element. Most structures that contain metal-polymer frictional units are grounded (such as drilling hoists, rail, etc.) or isolated from the Earth's surface, but have a fairly large metal and, therefore, electrical capacity (vehicles). To study the dependence of the insulation of a metal friction element on the wear of the surfaces of the friction facings for the laboratory installation, the following arrangements were simulated: stand not isolated (grounded) (Fig. 8, a) and brake pulley isolated from the brake drum (Fig. 8, b).

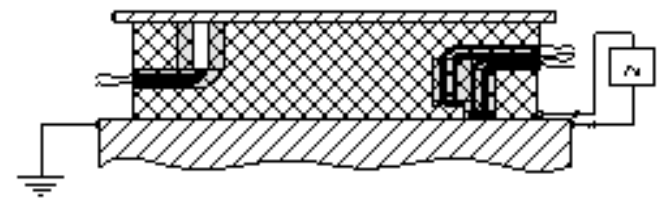

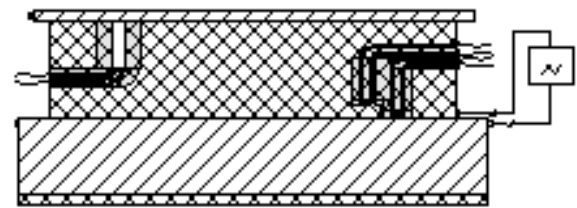

Fig. 8. Scheme of effect of isolation study of metal friction element on wear of surfaces of polymer facings for a serial friction unit (a) and with metal friction element with an isolatednon-workingsurface(b): 1 - tape;

2 - frictionfacing;

3 - abrakepulley;

4 - insulation

Fig. 9 illustrates regularities of changing values of linear wear of facing surfaces of the model of bandblock brake with insulated and uninsulated metal friction element with metallic polymer pairs of friction steel 34 L - retinax FC-24A. The studies were carried out at three hundred cyclic loads and tension of filling branch $S_{3}=800 \mathrm{~N}$ (Fig. 9, a) and $S_{3}=400 \mathrm{~N}$ (Fig. 9, b) for ten friction facings. It has been found that linear wear of friction surfaces for band-block brake with isolated metal friction elements, on average, $15-20 \%$ less than wear of surfaces of standard construction band-block brake with uninsulated metal friction element.

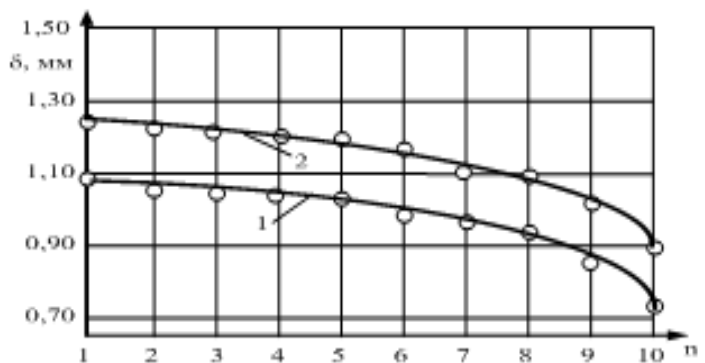

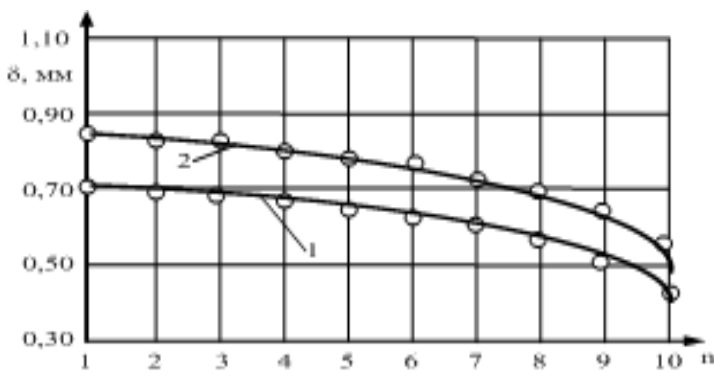

b

Fig. 9. Regularities of changes of linear regrouting values of the surfaces of facings of the band-block brake at tension

of unfilling branch of the band $S_{Z}=800 \mathrm{~N}$ (a) and $S_{Z}=400 \mathrm{~N}$ (b): 1 - for an isolated brake pulley; 2 - for serial friction unit

To determine the dependence of the insulation of metal friction element on the wear of the surfaces of friction facings of vehicle, operational tests of the unit for the development and repair of wells AORS-60 with brake drums production KrAZ were carried out. In one back brake mechanism, the drum was electrically insulated relative to the bridge, and the second brake mechanism remained in series.

Thus, linear wear of friction surfaces of friction facing for an improved band-block brake design with a tributary suppression system and isolation of the metal friction elements is, on average, $30-40 \%$ less than that of the brake facing surfaces.

Scientific results of investigations of triboelectric processes in metal-polymer friction pairs are obtained

As a result of the researches of wear-friction properties of metal-polymer friction pairs of brake devices in laboratory and operational conditions during triboelectric interaction the following regularities of change are established:

- thermostimulated currents generated on surfaces of metal-polymer friction pairs from the time of friction interaction and the surface temperatures of friction pairs; 
- electric potential in contact of friction pairs from the time of friction interaction and surface temperature of the facings;

- dynamic friction coefficients of serial and advanced brake mechanisms with device of reduction of tribocurrents in metal-polymer friction pairs;

- wear of surfaces of friction facings taking into account triboelectric currents on friction surfaces of the braking devices.

Influence of features of the design of brake mechanisms on circulation of tribocurrents in them, as a consequence, on the emergence, development and propagation of a network of microcracks in zones of maximum tribostrums is established. As a result of conducted researches it is established that during the triboelectric interaction the intensity of change of dynamic friction coefficients and linear wear in friction units of band-block and drum-block brakes depends on different types of contacts with variable energy activity, which cause instantaneous change of current momentum of metal-polymer friction pairs.

\section{Practical recommendations}

Performed researches can be used for improvement of design and operational parameters of brake devices of motor transport, at designing of brake mechanisms of cars of various purpose, estimation of operational parameters of brake devices. It will shorten the timing of development of new brake device designs and allow to choose the most effective technical solutions at an early stage of design.

\section{Conclusions and prospects for development of the direction}

As a result of researches of friction properties of metal-polymer friction pairs of brake devices in laboratory and operational conditions during triboelectric interaction regularities of change are established: dynamic coefficients of friction from generated tribocurrents in contact of two-layer metal-polymer structures; wear in friction pairs of "metal - polymers" of brake units from the values of circulating tribocurrents.

Obtained results allow us to optimize management of the wear-friction properties and thermal state of brake units. Further studies will be relating with more detailed study of contact potential difference effect on wear of friction surfaces of braking devices.

\section{References}

1. Hang, Y. Trib-electrification mechanisms for self matedcarbon steels in dry severe wear process / Y. Hang, J. Yur, H. Chou // Wear. - 2006. - Vol. 260, Iss. 11-12. - P. 1209-1216.

2. Вольченко Н. А. Работоспособность многопарных фрикционных узлов в ленточноколодочном тормозе буровой лебедки / Н. А. Вольченко, Д. А. Вольченко, С. И. Криштопа, Д. Ю. Журавлев, А. В. Возный // Розвідка та розробка нафтових і газових родовищ. - Івано-Франківськ, 2012. - № 2(43). - с. $40-48$.

3. Krawczyk, K. Możliwości sterowania siłą tarcia za pomocą prądu elektrycznego przepływającego przez strefę tarcia / K. Krawczyk, E. Nowiński, A. Chojnacka // Tribologia: tarcie, zużycie, smarowanie. - 2011. - № 2. - Р. 61-70.

4. Левыкин, Д. А. Математическая модель электрического контакта шероховатых поверхностей / Д. А. Левыкин // Программные продукты и системы. - 2011. - № 4. - С. 178-180.

5. Измайлов, В. В. Контакт твердых тел и его проводимость / В. В. Измайлов, М. В. Новоселов. Тверь: Изд-во ТГТУ, 2010. - 112 с.

6. Rozenbaum, V. M., Tsmchik, O. Ye. (2010). Analytical Description of Currents of Thermostimulation Polarization and Depolarization. Physics of solid, Vol. 52, Iss. 10, 2046-2051.

7. Pashayev, A. M., Janahmadov, A. K., Dyshin, O. A., Javadov M. Y. The Multi-Fractal Analysis of Fatigue Facture under Friction Process. Journal Science and applied engineering. - 2013. - Vol. 1. - pp. 112-116.

8. Износ фрикционных накладок при контактно-импульсном взаимодействии металлополимерных пар трения ленточно-колодочного тормоза / М. В. Киндрачук, Н. А. Вольченко, Д. А. Вольченко [и др.] // Проблемы трения и износа: научн.-техн. сб. - К.: НАУ, 2013. Вып. 2 (61). - С. 4-19.

9. Janahmadov, A. K., Volchenko, A. I., Javadov, M. Y., Volchenko, D. A., Volchenko, N. A., Janahmadov, E. A. The Characteristic Analysis of Changes in the Processes, Phenomena and Effects within Working Layers of Metal Polymer Pairs During Electro-Thermo-Mechanical Friction. Science \& Applied Engineering Quarterly. - 2014. - Vol. 2. - pp. 6-17.

10. Мамедов Р. К. Контакты металл-полупроводник с электрическим полем пятен / Р. К. Мамедов. - Баку: Госуниверситет, 2013. - 231 с.

11. Электромеханический износ и разрушение ободов тормозных шкивов буровых лебедок (часть вторая) / А. И. Вольченко, Н. А. Вольченко, М. Я. Джавадов [и др.] // Проблемы трения и износа: научн.-техн. сб. - К.: НАУ, 2014. Вып. 3 (64). - С. 4-17. 
12. Kryshtopa, S., Kryshtopa, L., Bogatchuk, I., Prunko,I., Melnyk, V. Examining the effect of triboelectric phenomena on wear-friction properties of metal-polymeric frictional couples. Eastern-European J. Enterprise Techn - 2017. - 1, № 5(85). - P. 40-45.

13. Galikhanov, M. F. Polymeric Composition Corona Charge Elects: abstract (2009). Thesis on competition of a scientific degree of doctor of engineering science on a speciality 05.17.06, Kazan, $35 \mathrm{p}$.

14. Вольченко О. І. Електродинамічні процеси та їхній вплив на знософрикційні властивості металополімерних пар тертя гальмівних приладів / О. І. Вольченко, С. І. Криштопа, В. І. Карась // Зб. наук. пр. СевНТУ. - Севастополь, 2012. - Вип. 135. - С. 237-240.

15. Janahmadov, A. K., Aliev, A. M., Volchenko, A. I., Javadov M. Y. Band-block brake with conductive cooling. SRI researcher notes "Geotechnological Problems of Oil, Gas and Chemistry", Baku. - 2013. - pp. $113-119$.

16. Volchenko, A. I., Kindrachuk, M. V., Volchenko, D. A. (2015). Tribology: Electrothermomechanic Bases, Analysis and Synthesis at Nano-, Mikro- and Millelevels and Technical Applications: textbook for higher education institutes. Kyiv-Krasnodar, 371 p.

Криштопа С.І., Криштопа Л.І., Козак Ф.В., Мельник В.М., Дикун Т.В., Цебер М. М. Шляхи зменшення зносу поверхонь тертя за допомогою трибоелектричних явищ

Експериментальні дослідження трибоелектричних явищ були виконані на спеціально створених лабораторних стендах, що моделювали різні типи гальм та на серійному універсальному автомобільному гальмівному стенді моделі КИ-8964. Вимірювання трибоелектричних струмів здійснювалось за допомогою наноамперметра, а різниця потенціалів в парах тертя - за допомогою аналого-цифрового перетворювача USB Oscilloscope II та ноутбука з спеціальним програмним забезпеченням.

У результаті проведених досліджень зношувальних властивостей металополімерних пар тертя гальмівних механізмів у виробничих та лабораторних умовах під час трибоелектричного тертя встановлені закономірності зміни: величин циркулюючих трибострумів в парах тертя «чавун - полімер» барабанно-колодкових та стрічково-колодкових гальм від поверхневої температури фрикційних вузлів та кількості циклів гальмувань; динамічного коефіцієнта тертя від величин циркулюючих трибострумів; величин лінійного зношування пар тертя гальмівних пристроїв від зміни генерованих трибострумів в контакті двошарових структур «метал-полімер».

Виконані дослідження трибоелектричних процесів дозволяють розширити базу даних щодо механізмів трибоелектричних явищ в металополімерних парах тертя. У результаті виконаних досліджень знософрикційних властивостей металополімерних пар тертя гальмівних пристроїв у виробничих та лабораторних умовах під час трибоелектричної взаємодії встановлені закономірності зміни динамічних коефіцієнтів тертя та зношування фрикційних поверхонь від величин генерованих трибострумів, часу фрикційної взаємодії та поверхневої температури металополімерних пар тертя.

Одержані результати дозволяють знизити зношування металополімерних фрикційних поверхонь та оптимізувати знософрикційні властивості вузлів тертя.

Ключові слова: барабанне гальмо, стрічкове гальмо, дискове гальмо, металополімерні поверхні тертя, трибосистема, трибоелектричні процеси. 